УДК 347.9

DOI https://doi.org/10.32849/2663-5313/2019.9.07

\title{
Тетяна Цувіна,
}

канд. юрид. наук,

доцент кафедри цивільного процесу

Національного юридичного університету імені Ярослава Мудрого

\section{ПРИНЦИП RESJUDICATA У ЦИВІЛЬНОМУ СУДОЧИНСТВІ}

Статтю присвячено вивченню базових підходів, вироблених у практииі Європейського суду з прав людини, до інтерпретаиї такої вимоги правової визначеності, як правило res judicata, в контексті тлумачення n. $1 \mathrm{~cm} .6$ Конвениії про захист прав людини та основоположних свобод, що закріплює право кожного на справедливий судовий розгляд у иивільних справах.

На підставі аналізу зроблено висновок, що зміст правила res judicata у иивільному судочинстві зводиться до таких положень: а) сторони не мають права вимагати перегляду остаточного i обов'язкового судового рішення лише з метою проведення повторного слухання $і$ нового вирішення справи, повноваження судів вищої інстаниї щодо перегляду справ можуть використовуватися виключно для виправлення істотних судових помилок, фундаментальних дефектів провадження, перегляду неправомірних судових рішень, тобто мають існувати істотні підстави для перегляду остаточних та обов'язкових судових рішень; б) посадові особи держави, які не були стороною у справі, не повинні мати необмеженого часовими рамками права звертатися до суду зі скаргою на остаточне судове рішення з метою його скасування; в) процесуальні правила оскарження судових рішень щодо належних суб'єктів та строків оскарження, неможливості безпідставного поновлення строків оскарження, дотримання вимог до форми і змісту апелячійної та касаційної скарг тощо мають неухильно дотримуватися; г) новий розгляд справи за тотожним позовом, а також можливість обходу остаточних судових рішень шляхом подачі нових позовів до суду, які, хоча і не є тотожними, однак грунтуються на тих самих фактичних обставинах справи та мають на меті новий розгляд та вирішення справи, якщо у справі вже ухвалене остаточне рішення, є недопустимим; д) факти, встановлені в рішенні суду, що набрало законної сили, під час наступного розгляду справ між иими самими сторонами вважаються преюдииійними та не повинні встановлюватися повторно.

Ключові слова: правова визначеність, res judicata, право на справедливий судовий розгляд, верховенство права, преюдиційні факти.

Постановка проблеми. Правова визначеність визнається однією з фундаментальних вимог верховенства права в демократичних державах, що покликана забезпечити стабільність правозастосування. Питанню дослідження структурно-функціональної характеристики принципу правової визначеності приділяється увага Венеціанської комісії, яка виокремлює серед основних її елементів: а) доступність законодавства; б) доступність судових рішень; в) сталість і послідовність правових актів; г) сталість та послідовність приписів права; д) концепцію легітимних очікувань; е) неможливість зворотної сили закону; є) принципи nullum crimen sine lege та nullum poena sine lege; е) правило res judicata [1]. Велику увагу у своїй практиці тлумаченню принципу правової визначеності приділяє і Європейський суд з прав людини (надалі - ССПЛ), надаючи інтерпретацію окремим його складовим під час тлумачення різних статей Конвенції про захист прав людини та основоположних свобод (надалі - ЄКПЛ). Не оминають увагою окреслену проблематику також вітчизняні і зарубіжні вчені, серед яких варто згадати дослідження Л.Л. Богачової, I.I. Дахової, Дж. Мексеньєра (J. Maxenier), C.П. Погребняка, П. Попелієра (Р. Popelier), Дж. Раітіо (J. Raitio), М. Фенвіка (M. Fenwick) та ін. Поряд із цим вищенаведені розвідки, як правило, проводяться через призму загальної теорії права, натомість наразі особливої актуальності набувають дослідження дії загальних принципів права в окремих галузях, зокрема у цивільному судочинстві. Із цієї точки зору ключове значення для дослідження дії принципу правової визначеності у цивільному судочинстві має вивчення такого іï елементу, як правило res judicata, що розглядається як принцип остаточності судових рішень та одночасно визнається гарантією права на справедливий судовий розгляд у цивільному судочинстві, закріпленого в п. 1 ст. 6 ЄКПЛ. 
|| Метою статті є дослідження сутності res judicata як елемента принципу правової визначеності у цивільному судочинстві крізь призму положень п. 1 ст. 6 ЄКПЛ, що закріплює право на справедливий судовий розгляд у цивільних справах, та практики ЄСПЛ щодо тлумачення цієї статті.

Виклад основного матеріалу. ССПЛ у своїх рішеннях неодноразово зазначав, що право на справедливий судовий розгляд, гарантоване п. 1 ст. 6 ЄКПЛ, повинно тлумачитися у світлі Преамбули до ЄКПЛ, яка проголошує верховенство права частиною спільної спадщини Договірних Держав. Одним 3 основних аспектів верховенства права $€$ принцип правової визначеності, який передбачає, серед іншого, що ухвалене судами остаточне рішення не може ставитися під сумнів [2]. Правова визначеність передбачає повагу до принципу res judicata, що є принципом остаточності судових рішень. Він, зокрема, означає, що жодна зі сторін не має права вимагати перегляду остаточного і обов'язкового судового рішення лише 3 метою проведення повторного слухання і нового вирішення справи. Повноваження судів вищої інстанції щодо перегляду справ мають використовуватися для виправлення судових помилок та неправомірних судових рішень, а не для проведення нового розгляду справи. Перегляд справи не може розглядатися як замаскована апеляція, а сама лише можливість існування двох поглядів на одне питання не $\epsilon$ підставою для повторного розгляду справи. Відхилення від цього принципу можливе лише тоді, коли воно спричинене незалежними і непереборним обставинами [3; 4; 5]. Аналіз практики ССПЛ щодо тлумачення п. 1 ст. 6 ЄКПЛ дозволяє виокремити декілька елементів res judicata у цивільному судочинстві, на яких слід зупинитися детальніше.

1. Істотність підстав для перегляду остаточного та обов'язкового судового piшення. Вимоги правової визначеності у частині правила res judicata не є абсолютними, адже ЄСПЛ сам інколи рекомендуе поновлення провадження в національних судах як належний відновлювальний захід, якщо попередній розгляд справи не відповідав вимогам п. 1 ст. 6 ЄКПЛ [6; 7; 8; 9; 10]. При цьому саме державні органи влади мають оцінити можливість такого поновлення на відповідність принципу правової визначеності та дотримання балансу публічних та приватних інтересів [7; 11].

У справі Ryabykh v. Russia [3] легітимними підставами для перегляду судових рішень, що набрали законної сили, в кон- тексті дії принципу res judicata, передусім, визнається наявність судових помилок та неправомірних судових рішень. У більш пізній практиці ЄСПЛ як підстави для перегляду називає «фундаментальні дефекти» ("fundamental defects", що інколи перекладається, як “істотні недоліки”) у провадженні, допущені судами нижчих інстанцій [12; 13; 14; 15; 16], зазначаючи також, що відхилення від принципу res judicata можливе лише тоді, коли воно спричинене суттєвими і непереборним обставинами [14], а також у випадках, коли це обгрунтовується нагальною суспільною потребою, а не просто правовим пуризмом [17]. Наприклад, такими «фундаментальними дефектами» визнавалися випадки, коли: а) суд вирішував питання про права та обов'язки особи, яка не була залучена до участі у справі [12], враховуючи незалучення до участі у справі держави, коли під час провадження вирішувалися питання, що зачіпали їі інтереси [18]; б) особа не могла брати участь у провадженні ефективно [19; 20]; в) були встановлені нововиявлені обставини [21]; г) мали місце юрисдикційні помилки, серйозні порушення процесуального законодавства або зловживання владою [22] тощо.

Натомість не визнавалися «фундаментальними дефектами», а відтак і належними підставами для перегляду остаточного судового рішення, що набуло статусу res judicata: а) можливість різної інтерпретації поданих сторонами доказів [7; 10]; б) подача нових доказів у цивільній справі без належного з'ясування судом питання про те, чому нова інформація та докази не могли бути отримані та подані під час первісного розгляду справи [23]; в) можливість різного тлумачення правових актів [24]; г) незгода вищестоящих судів із тлумаченням норм матеріального права, наданих нижчестоящими судами [14; 25; 26; 27], особливо якщо в державі відсутня усталена практика з певного питання [28] тощо. Більш того, ЄСПЛ зазначає, що забезпечення одноманітного застосування національного законодавства $є$ важливим, однак не повинно досягатися за будь-яку ціну i, особливо, за рахунок зневажання законної впевненості заявника у принципі правової визначеності [26; 29; 30;31].

Разом із тим неважко помітити, що поняття «фундаментальний дефект» є оціночними, а тому його тлумачення має відбуватися з урахуванням конкретних обставин справи. Так, у справі "Sutyazhnik v. Russia" ЄСПЛ розглядав питання про те, чи можна вважати фундаментальним дефектом провадження, що має тягти за собою перегляд судового рішення, яке вступило в законну 
силу, порушення правил предметної юрисдикції. У цьому контексті ССПЛ зазначив, що в певних випадках можливе відступлення від правової визначеності з метою виправлення «фундаментальних дефектів» або перегляду «неправомірного судового рішення», проте зазначені поняття не мають чіткого визначення. Надалі ЄСПЛ зазначив, що в принципі судові помилки можна розглядати в якості «фундаментальних дефектів», що підлягають виправленню в порядку процедури нагляду. При цьому виникає питання, чи може за певних обставин справи порушення правил юрисдикції розглядатися як «фундаментальний дефект», що вимагає перегляду рішення, яке заявник вважав таким, що вступило в законну силу. 3 обставин цієї справи випливає, що спір сторін стосувався державної реєстрації громадських організацій i розглядався арбітражними судами двох інстанцій, після чого рішення суду не оскаржувалося самими сторонами. Натомість перегляд у порядку нагляду був ініційований Заступником голови Вищого арбітражного суду на підставі того, що після розгляду справи заявника в національних судах мало місце роз'яснення правил юрисдикції у цій категорії справ, відповідно до яких спір підлягав розгляду в порядку цивільного, а не арбітражного судочинства. Ухвалюючи рішення у цій справі, ССПЛ зауважив, що він бере до уваги той факт, що правил юрисдикції слід дотримуватися, однак зважаючи на конкретні обставини справи, ЄСПЛ не знаходить нагальної суспільної потреби, яка могла б виправдати відступлення від принципу правової визначеності. Рішення у справі заявника було скасоване судом найвищої інстанції скоріше заради правового пуризму, ніж для того, щоб виправити істотну судову помилку [17].

2. Несумісність із принщипом res judicata права посадових осіб держави, які не були стороною у справі, звертатися до суду зі скаргою на остаточне судове рішення з метою його скасування, особливо якщо таке право не обмежене часовими рамками та коли рішення суду вже було виконане [2; 3; 32]. Фактично йдеться про несумісність із вимогами правової визначеності інституту внесення протесту в порядку нагляду, що існував до 2004 року в законодавстві України і наразі продовжує існувати в деяких зарубіжних державах. ЄСПЛ вказує, що право сторони на суд буде рівною мірою ілюзорним, якщо правова система договірної держави передбачає скасування судового рішення, що стало остаточним та обов'язковим, вищестоящим судом за протестом, винесеним посадовою особою держави [3]. ЄСПЛ вважає, що судова система, в якій існує процедура внесення протесту та аналогічні до неї процедури, а відтак можливість неодноразового скасування остаточного судового рішення, не відповідає як така принципу правової визначеності, який становить один 3 основних елементів верховенства права в сенсі п. 1 ст. 6 ЄКПЛ [2; 32]. Зокрема, порушення п. 1 ст. 6 ЄКПЛ неодноразово визнавалися у випадках, коли необмежене часовими межами право оскарження судового рішення, що набрало законної сили та стало остаточним, мали посадові особи держави, що не брали участі у провадженні в судах нижчих інстанцій, як прокуpop [2; 33], Генеральний прокурор [2; 10; 24; 34] або судді вищих судів, зокрема Голова Верховного Суду [4], заступник голови ВСУ [35], голова апеляційного суду [3], заступник голови апеляційного суду [36] тощо.

3. Неухильне дотримання процесуальних правил щодо належних суб'єктів оскарження. Порушення правила res judicata має місце у випадку, коли всупереч нормам національного законодавства суди приймають до розгляду скарги осіб, які не мають права на оскарження судових рішень, і в подальшому скасовують такі рішення за результатами розгляду цих скарг. Так, у справі "Diya 97 v. Ukraine" [37] Верховний Суд України задовольнив касаційну скаргу особи, яка не брала участь у справі, та змінив рішення судів попередніх інстанцій всупереч положенням чинного на час розгляду справи законодавства, відповідно до якого особи, не залучені до провадження на попередніх стадіях, не мали права на подання відповідної скарги. Аналогічна ситуація мала місце у справі "Industrial Financial Consortium Investment Metallurgical Union v. Ukraine" [24], де перегляд за нововиявленими обставинами був здійснений за заявою осіб, які не брали участі в первісному провадженні, а отже, не могли за чинним на момент розгляду справи законодавством подавати відповідні заяви.

4. Неможливість перегляду судових рішень поза встановленими законом строками оскарження та безпідставного поновлення таких строків. Аналогічно до скасування судового рішення в порядку нагляду законні очікування сторони, що виграла справу, з точки зору принципу res judicata можуть бути підірвані поновленням строків оскарження зі спливом значного періоду часу [26; 38]. ЄСПЛ підкреслює, що саме національні суди наділені дискреційними повноваженнями щодо розгляду питання про поновлення строків оскарження судових рішень, однак їхня свобода розсуду не є необмеженою: в кожному конкретному 
випадку національні суди мають встановити, чи виправдовують причини поновлення строку оскарження втручання у принцип res judicata, особливо якщо національне законодавство не обмежує дискреційні повноваження судів стосовно часу або підстав для поновлення пропущеного строку [39; 40].

Зважаючи на те, що концепція «поважних причин» не є чіткою [41; 42], для національних судів ще більш важливою є необхідність вказувати причини свого рішення у частині поновлення пропущеного строку і відновлення провадження у справі, тобто такі рішення судів мають бути належним чином вмотивованими [24; 39; 40]. Порушенням п. 1 ст. 6 ЄКПЛ неодноразово визнавалися випадки поновлення строку оскарження судових рішень через тривалий проміжок часу не заради виправлення фундаментальних дефектів провадження, а лише з метою повторного розгляду справи та ухвалення нового рішення [39], зокрема, коли під час поновлення строків оскарження та подальшого скасування судових рішень попередньої інстанції суди не наводили жодних поважних причин для поновлення строків, обмежувалися вказівкою на наявність поважних причин, не розкриваючи їх суті, або ж констатували наявність поважних причин без належного дослідження доказів їх наявності або взагалі за відсутності таких доказів [40; 43; 44]. Так, у справі "Karen Pogosyan v. Armenia” апеляційний суд поновив строк апеляційного оскарження за скаргою прокурора через 8 років після ухвалення рішення, не дослідивши докази поважності пропуску строку на оскарження. ЄСПЛ, оцінюючи зазначену ситуацію, зазначив, що у цьому випадку апеляційний суд знехтував своїм обов'язком визначити наявність поважних причин, що виправдовували б прийнятність апеляційної скарги після спливу такого великого строку, здійснити всебічне дослідження такого серйозного питання та відповідно впевнитися в дотриманні справедливого балансу між інтересами заявника та необхідністю належного здійснення правосуддя, що включає дотримання інтересів третіх сторін [18]. ЄСПЛ визнавав порушення п. 1 ст. 6 ЄКПЛ саме із цієї причини і в рішеннях проти України, зокрема у справах "Ponomaryov v. Ukraine" [39] та "Ustimenko v. Ukraine” [40], де строки касаційного оскарження були безпідставно поновлені національними судами зі спливом більш ніж двох років та одного року відповідно. Поряд із цим в інших справах безпідставне поновлення через більш короткі строки, наприклад чотири місяці після ухвалення остаточного рішення [24], також визнавалося таким, що порушує право на справедливий судовий розгляд.

У своїй практиці ЄСПЛ не визнавав поважними причинами пропуску строків оскарження судових рішень, наприклад, посилання заявників на складне економічне становище та відсутність вільних коштів у підприємства, що нібито перешкоджало відповідачу сплатити державне мито, хоча останній навіть не намагався скористатися процедурами відстрочення та розстрочення сплати судових витрат [39]. Натомість поважною причиною визнавалося неповідомлення сторін про ухвалені у їхній справі рішення. Проте навіть у цьому випадку можливість поновлення не визнається абсолютною та має оцінюватися, виходячи 3 обставин конкретної справи, оскільки сторони в розумні інтервали часу мають вживати заходів, щоб дізнатись про стан відомого їм судового провадження [45; 46].

5. Заборона нового розгляду справи за тотожним позовом, якщо у справі вже ухвалене остаточне рішення. Принцип res judicata передбачає не лише повагу до рішення суду з точки зору використання процедур оскарження, однак і з точки зору неможливості повторного звернення до суду 3 тотожним позовом. Інакше кажучи, відповідно до цього принципу справа, що вже була вирішена судом, не може стати предметом нового судового розгляду. Так, у справі "Yushchenko and others v. Ukraine" заявник просив ЄСПЛ визнати таким, що суперечить п. 1 ст. 6 ЄКПЛ ситуацію, за якої вимоги, у задоволенні яких було відмовлено під час розгляду справи в порядку цивільного судочинства, в подальшому стали предметом цивільного позову в кримінальному провадженні, що був задоволений судом. 3 обставин справи випливає, що під час провадження в порядку цивільного судочинства позивач не надав суду достатніх доказів для підтвердження свої позовних вимог, унаслідок чого в задоволенні позову було відмовлено. Натомість зазначені докази були отримані пізніше, під час кримінального провадження щодо шахрайства, що мало наслідком подання до суду фактично тотожного цивільного позову, однак вже в рамках кримінального провадження, що був у подальшому задоволений судом. У цій справі ССПЛ зазначив, що за результатами першого провадження національний суд відхилив позовні вимоги до першого заявника про витребування речей, хоча згодом визнав, що перший заявник та його син забрали речі позивача. ЄСПЛ визнає, що в ході провадження у кримінальній справі заявника вирішувалися питання кримінального законодавства, які 
відокремлені від тих, що вже були вирішені під час провадження у цивільній справі. Хоча може видатися, що в обох провадженнях суди розглядали ту саму фактичну ситуацію і дійшли різних висновків, ЄСПЛ зазначає, що в цивільній справі суд не встановлював, що перший заявник не забирав речі. Однак цивільний аспект кримінальної справи стосувався того самого питання, що й цивільне провадження, яке відбулося раніше, а саме питання цивільно-правової відповідальності за заволодіння речами, а також їхню вартість. За відсутності будь-яких ознак того, що в цивільному провадженні мали місце певні вади, ЄСПЛ вважає, що нове вирішення тих самих питань звело нанівець закінчене раніше провадження, а це несумісне з принципом правової визначеності [47].

6. Неможливість обходу остаточних судових рішень иляхом подачі нових позовів до суду, які, хоча і не є тотожними, однак грунтуються на тих самих фактичних обставинах справи та мають на меті новий розгляд та вирішення справи. Окрім неможливості повторного розгляду справ за тотожними позовами, ССПЛ також зауважує на недопустимості ініціювання нових проваджень, які хоча і не є тотожними, однак спрямовані на подолання законної сили остаточних судових рішень. Так, у справі "Brletic v. Croatia" чоловік заявниці у 2002 році отримав рішення суду щодо стягнення на його користь заробітної плати, яке було виконане. Згодом чоловік помер, а заявниця була визнана його спадкоємицею. У 2008 році іншим судом першої інстанції було ухвалене рішення про задоволення кондикційного позову компанії щодо стягнення із заявниці суми заробітної плати, зайво сплаченої її чоловіку. Рішення суду обгрунтовувалося тим, що під час первісного розгляду справи іншим судом була неправильно обрахована сума заборгованості по заробітній платі: суд не врахував суму коштів, виплачених безпосередньо кредиторам чоловіка заявниці, внаслідок чого компанія здійснила виплати двічі: одразу безпосередньо кредиторам, а надалі - ï чоловіку за рішенням суду, внаслідок чого іiі чоловік безпідставно збагатився. Зазначеним рішенням суду із заявниці було стягнено на користь компанії заробітну плату в розмірі, в якому компанія свого часу здійснила виплати безпосередньо кредиторам чоловіка заявниці. ЄСПЛ, розглядаючи зазначену справу, зазначив, що навіть якщо пристати на позицію, що зазначені справи не були ідентичними, вони, тим не менше, відповідно до національного законодавства стосувалися один і тих самих сторін, а також одних і тих самих правовідносин та фактичних обставин справи, а саме виплати частини заробітної плати чоловіка заявниці в період із травня 1998 по січень 1999 року, що було визначальним для вирішення спору, та обидва провадження стосувалися один i тих самих матеріальних питань. Під час другого провадження суд знехтував висновками іншого суду щодо фактичних обставин справи, досягнутих за результатами першого провадження та відтворених у рішенні суду, що набрало законної сили. Друге провадження, таким чином, надавало компанії «другий шанс» для вирішення спору, який вже був вирішений судом, що свідчить про порушення п. 1 ст. 6 ЄКПЛ [48].

7. Урахування преюдиційного значення фактів, встановлених у рішенні, що набрало законної сили, під час наступного розгляду справ між цими самими сторонами. Принцип res judicata вимагає, серед іншого, також і правильного застосування положень законодавства щодо правил преюдиції у цивільному судочинстві, що, з одного боку, відбиває повагу до остаточних судових рішень, а з іншого - сприяє процесуальній економії та підвищенню ефективності відправлення правосуддя у цивільних справах. Так, у справі "Esertas v. Lithuania" в національних судах одне після одного було порушено два провадження між теплопостачальною компанією та заявником щодо стягнення заборгованості за надані послуги, проте під час першого провадження було встановлено факт відсутності договору між сторонами, натомість під час другого провадження зазначений факт знову був розглянутий судом та була констатована наявність договірних відносин між сторонами. Розглядаючи зазначену справу, ЄСПЛ зауважив, що обидва провадження стосувалися одних і тих самих сторін - теплопостачальника та заявника - та суть спору була однаковою, інакшим був лише період, за який стягувалася заборгованість. Не можна ігнорувати той факт, що обидва судові провадження стосувалися одних і тих самих правовідносин та одних і тих самих фактичних обставин справи, що були визначальними для вирішення спору. У цій справі не ставилося питання про скасування першого рішення, однак у другому провадженні питання щодо договірних правовідносин та теплопостачання було заново розглянуте та було ухвалене протилежне рішення. ЄСПЛ вважає, що ситуація, за якої фактичні обставини, що були встановлені в остаточному судовому рішенні в одній справі, пізніше спростовуються судом у новій справі між тими самими сторонами, є тотожною ситуації, у якій 
завдяки новому розгляду справи, в якій ухвалене остаточне та обов'язкове рішення, останнє скасовується повністю. Зазначена ситуація суперечить принципу правової визначеності. У зазначеній справі обставини, встановлені першим рішенням, були переоцінені та спростовані судом у другому провадженні. ССПЛ не може знайти виправдання вимозі до заявника доводити факт відсутності договірних відносин із теплопостачальником та відсутність постачання тепла до квартири, враховуючи, що ці обставини вже з'ясовувалися в першому провадженні. При цьому на жодні нові обставини у цій справі сторони не посилалися [22].

\section{Висновки}

Таким чином, принцип res judicata є важливим аспектом принципу правової визначеності у цивільному судочинстві, що передусім передбачає повагу до судових рішень, що набули статусу остаточних та забезпечення стабільності правозастосування, зміст якого може бути зведений до наступних положень: а) сторони не мають права вимагати перегляду остаточного і обов'язкового судового рішення лише з метою проведення повторного слухання і нового вирішення справи, натомість повноваження судів вищої інстанції щодо перегляду справ можуть використовуватися виключно для виправлення істотних судових помилок, фундаментальних дефектів провадження, перегляду неправомірних судових рішень, тобто мають існувати істотні підстави для перегляду остаточних та обов'язкових судових рішень; б) посадові особи держави, які не були стороною у справі, не повинні мати необмеженого часовими рамками права звертатися до суду зі скаргою на остаточне судове рішення з метою його скасування; в) процесуальні правила оскарження судових рішень щодо належних суб'єктів та строків оскарження, неможливості безпідставного поновлення строків оскарження, дотримання вимог до форми і змісту апеляційної та касаційної скарг тощо мають неухильно дотримуватися; г) новий розгляд справи за тотожним позовом, а також можливість обходу остаточних судових рішень шляхом подачі нових позовів до суду, які, хоча і не є тотожними, однак грунтуються на тих самих фактичних обставинах справи та мають на меті новий розгляд та вирішення справи, якщо у справі вже ухвалене остаточне рішення, $є$ недопустимим; д) факти, встановлені в рішенні суду, що набрало законної сили, під час наступного розгляду справ між цими самими сторонами вважаються преюдиційними та не повинні встановлюватися повторно.

\section{Список використаних джерел:}

1. Rule of Law Checklist. Venice Commission of the Council of Europe. Council of Europe. 2016. URL : https://www.venice.coe.int/images/SITE\% 20IMAGES/Publications/Rule_ of_Law_Check_ List.pdf.

2. Brumărescu v. Romania, no. 28342/95, 28 October 1999. URL : http://hudoc.echr.coe.int/ eng? $=001-58337$.

3. Ryabykh v. Russia, no. 52854/99, 24 July 2003. URL : http://hudoc.echr.coe.int/eng?i=001-61261.

4. Driza v. Albania, no. 33771/02, 13 November 2007. URL : http://hudoc.echr.coe.int/eng?i=00183245 .

5. Oferta Plus SRL v. Moldova, no. 14385/04, 19 December 2006. URL: http://hudoc.echr.coe.int/ eng? $\mathrm{i}=001-78585$

6. Lungoci v. Romania, no. 62710/00, 26 January 2006. URL : http://hudoc.echr.coe.int/eng?i=00172174 .

7. Mitrea v. Romania, no. 26105/03, 29 July 2008. URL : http://hudoc.echr.coe.int/eng?i=001-87962.

8. Moreira Ferreira v. Portugal (no. 2) [GC], no. 19867/12, ECHR 2017. URL : http://hudoc. echr.coe.int/eng?i=001-175646.

9. S.C. Textinc S.A. v. Romania, no. 52018/10, 06 February 2018. URL : http://hudoc.echr.coe.int/ eng?i=001-180548.

10. Gridan and others v. Romania, no. 28237/03, 04 June 2013. URL : http://hudoc.echr.coe.int/ eng? $\mathrm{i}=001-120706$.

11. Nikitin v. Russia, no. 50178/99, ECHR 2004-VIII. URL : http://hudoc.echr.coe.int/ eng? $\mathrm{i}=001-61928$.

12. Protsenko v. Russia, no. 13151/04, 31 July 2008. URL : http://hudoc.echr.coe.int/eng?i=00187892 .

13. Dovguchits v. Russia, no. 2999/03, 07 June 2006. URL : http://hudoc.echr.coe.int/eng?i=00180929.

14. Kot v. Russia, no. 20887/03, 18 January 2007. URL : http://hudoc.echr.coe.int/eng?i=001-79134.

15. Zelenkevich and others v. Russia, no. 14805/02, 20 June 2013. URL : http://hudoc.echr.coe.int/ eng? $\mathrm{i}=001-120963$.

16. Shchurov v. Russia, no. 40713/04, 29 March 2011. URL : http://hudoc.echr.coe.int/eng?i=001104139 .

17. Sutyazhnik v. Russia, no. 8269/02, 23 July 2009. URL : http://hudoc.echr.coe.int/eng?i=00193775 .

18. Karen Poghosyan v. Armenia, no. 62356/09, 31 March 2016. URL : http://hudoc.echr.coe.int/ eng? $\mathrm{i}=001-161735$.

19. Tishkevich v. Russia, no. 2202/05, §§ 25-27, 4 December 2008. URL : http://hudoc.echr.coe.int/ eng? $\mathrm{i}=001-89902$.

20. Tolstobrov v. Russia, no. 11612/05, 4 March 2010. URL : http://hudoc.echr.coe.int/eng?i=00197561.

21. Zheltyakov v. Ukraine, no. 4994/04, 09 June 2011. URL : http://hudoc.echr.coe.int/eng?i=001104903. 
22. Esertas v. Lithuania, no. 50208/06, 31 May 2012. URL : http://hudoc.echr.coe.int/eng?i=001111215 .

23. Popov v. Moldova (no. 2), no. 19960/04, 6 December 2005. URL : http://hudoc.echr.coe.int/ eng?i $=001-71507$.

24. Industrial Financial Consortium Investment Metallurgical Union v. Ukraine, no. 10640/05, 26 June 2018. URL : http://hudoc.echr.coe.int/eng?i=001184068.

25. Davydov v. Russia, no. $18967 / 07,30$ October 2014. URL : http://hudoc.echr.coe.int/eng?i=001147440 .

26. Kulkov and Others v. Russia, no. 25114/03 08 January 2009. URL : http://hudoc.echr.coe.int/ eng?i $=001-90454$.

27. Eydelman and other «Emigrant Pensioners» Cases v. Russia, no. 7319/05, 04 November 2009. URL : http://hudoc.echr.coe.int/eng?i=001-101594.

28. Tarnopolskaya and others $v$. Russia, no. 11093/07, 09 July 2009. URL : http://hudoc.echr. coe.int/eng?i=001-93496.

29. Kirilenko v. Russia, no. 38597/07, 05 April 2011. URL : http://hudoc.echr.coe.int/eng?i=001104290.

30. Kazakevich and other "Army Pensioners" Cases v. Russia, no. 14290/03, 14 January 2010. URL http://hudoc.echr.coe.int/eng?i=001-96682.

31.Davletkhanov and other "Chernobyl Pensioners" Cases v. Russia, no. 7182/03, 23 Sepyember 2010. URL : http://hudoc.echr.coe. int/eng?i=001-100470.

32. Sovtransavto Holding v. Ukraine, № 48553/99, ECHR 2002-VII. URL : http://hudoc.echr.coe.int/ eng? $\mathrm{i}=001-60634$.

33. Rosca v. Moldova, no. 6267/02, 22 March 2005. URL : http://hudoc.echr.coe.int/eng?i=001-68580

34. Bîrlă v. Romania, no. 18611/04, 27 May 2010. URL : http://hudoc.echr.coe.int/eng?i=001-98932.

35. Tregubenko v. Ukraine, no. 61333/00, 02 November 2004. URL: http://hudoc.echr.coe.int/ eng?i=001-67248.
36. Svetlana Naumenko v. Ukraine, no. 41984/98 09 November 2004. URL : http://hudoc.echr.coe.int/ eng?i $=001-67357$

37. Diya 97 v. Ukraine, no. 19164/04, 21 October 2010. URL : http://hudoc.echr.coe.int/eng?i=001101189 .

38. Bezrukovy v. Russia, no. 34616/02, 10 May 2012. URL : http://hudoc.echr.coe.int/eng?i=001110806.

39. Ponomaryov v. Ukraine, no. 3236/03, 03 April 2008. URL : http://hudoc.echr.coe.int/eng?i=00185683.

40. Ustimenko v. Ukraine, no. 32053/13, 29 October 2015. URL : http://hudoc.echr.coe.int/ eng?i=001-158143.

41.H. v. Belgium, no. $8950 / 80,30$ November 1987, Series A № 127-B. URL : http://hudoc.echr. coe.int/eng?i=001-57501.

42. Georgiadis v. Greece, no. 21522/93, 29 May 1997. URL : http://hudoc.echr.coe.int/eng?i=00158037.

43. Osovska and others v. Ukraine, no. 2075/13, 28 June 2018. URL : http://hudoc.echr.coe.int/ eng? $\mathrm{i}=001-183950$.

44. Bodiu v. The Republic of Moldova, no. 7516/10, 18 June 2019. URL: http://hudoc.echr.coe. int/eng?i $=001-193874$

45. Aleksandr Shevchenko v. Ukraine, no. 8371/02, 26 April 2007. URL : http://hudoc.echr.coe.int/ eng?i $=001-80286$.

46. Trukh v. Ukraine, no. 50966/99,14 October 2003. URL : http://hudoc.echr.coe.int/eng?i=00123085.

47. Yushchenko and others v. Ukraine, no. $73990 / 01,15$ July 2010. URL : http:// hudoc.echr.coe.int/eng?i=001-99837.

48. Brletic v. Croatia, no. 42009/10, 16 January 2014. URL : http://hudoc.echr.coe.int/eng?i=001140018.

49. Kožemiakina v. Lithuania, no. 231/15, 02 October 2018. URL : http://hudoc.echr.coe.int/ eng?i=001-186438.

The article is devoted to the analysis of res judicata rule as an essential element of the legal certainty principle in terms of the evaluative interpretation of par. 1 art. 6 ECHR devoted to the right to a fair trial in civil procedure. Res judicata is considered to be one of the main guaranties of the legal certainty principle in civil procedure which allows a stability of the court decisions in democratic society and increase the public confidence to judiciary.

The author describes the following elements of res judicata: a) no party is entitled to seek a review of a final and binding judgment merely for the purpose of obtaining a rehearing and a fresh determination of the case, instead higher courts' power of review should be exercised to correct judicial errors and miscarriages of justice, but not to carry out a fresh examination; b) legal system couldn't allow a judicial decision which had become final and binding to be quashed by a higher court on an application made by a State official, who was not a party of the proceedings, specially if this power was not subject to any time-limit; c) special rules about time limits, persons, who can lodge an appeal, and procedural form of the appeal should be respected; d) after the court decision becomes final identical claim couldn't be the subject of a trial; e) there should be prejudicial effect of the facts, which were established in final court decision, for the further trials with the same parties.

Key words: legal certainty, res judicata, right to a fair trial in civil cases, rule of law, prejudicial effect. 